https://doi.org/10.18485/iipe_conv_conf.2021.ch5

\title{
THE PERSPECTIVE OF INTERNATIONAL INTERACTIONS IN THE POST-CORONA MULTIPOLAR WORLD (with an emphasis on Iranian-Islamic civilization)
}

\author{
Garineh Keshishyan Siraki ${ }^{1}$
}

\begin{abstract}
Deep and pervasive crises are among the events that may occur once a century and cause many changes in all areas and dimensions of human life. The outbreak of the coronavirus is one of the crises that affected all aspects of human life, so that the world underwent economic, political, cultural, social, structural and international order. In previous decades, changes in technology, the free flow of ideas, capital and services, and the existence of heterogeneous governments and actors with different demographics and power levels have resulted in diverse, complex, and asymmetric relationships beyond global geographical boundaries and global phenomena. This characterized the world led by the United States in the unipolar system after the collapse of the Soviet Union. But after the Corona crisis, a change in the status quo and an increase in the power of countries like China and Russia by creating cooperative dipoles was able to affect international interactions and upset the old equations. In such circumstances, the possibility of playing the role of "Iranian-Islamic civilization" as an emerging power, given its discourse power and emphasizing the "Theory of Resistance of the Iranian Supreme leader" in the field of military, economic, political and cultural deterrent power of the Islamic Republic of Iran, is very high. It was important under these circumstances, the possibility of changing the world order from uni-multipolar to multipolar conditions, the prospect of international interactions in the post-corona multipolar world, which was examined in this article.

Keywords: International Interactions, Multipolar World, Post-Corona, Theory of Resistance, Iranian-Islamic Civilization.
\end{abstract}

\footnotetext{
${ }^{1}$ Associate Professor of Political Science and International Relations, South Tehran Branch, Islamic Azad University, Tehran, Iran.g.keshishyan71@gmail.com, G_keshishyan@azad.ac.ir
} 


\section{INTRODUCTION}

Many international relations experts believe that the new world order is being formed by emerging powers, and some believe that emerging orders are being formed by emerging powers. The current situation promises a multidimensional order and a multipolar world, and the world is evolving towards a new geometry in such a way that the gradual transfer of power can be the basis for a transition to a just and humane order.

On the other hand, in the fluidity of the changing international system and in the current mono-polar situation, there is still no definite or established order that indicates the dominance of one trend over other trends or the domination of one actor over other actors. Such a fluid and transitional situation can be affected by the atmosphere of globalization, the emergence of emerging powers, the emphasis on the role of the media, the formation of network power, and the emergence of pervasive crises, including the COVID-19 crisis, which is one of the most important issues that has overshadowed international interactions. The "New Security Riddle" feature can also create new complex, transnational, regional, and globallocal connections.

"Changes in technology, the free flow of ideas, goods, capital, and services in an interdependent world, and the existence of heterogeneous governments and actors with different geographical sizes, demographic compositions, and power levels result in diverse, complex, and asymmetric relationships across geographical boundaries has become global. In the interconnected world in general, countries need to cooperate in global affairs. In the meantime, interactions and connections between different units in the world system are not limited to heads of state, but also citizens have interacted with each other with similar social and economic interests, creating subsystems separate from the spider web system of their governments. The interaction between these subsystems has placed the world community as a spider web in an intertwined system and complex network."

In such circumstances, the possibility of playing the role of "Iranian-Islamic Civilization" as an emerging power, given its discourse power and emphasising

2 John W. Burton, World Society, (Cambridge University Press, 1972). 
the "Theory of Resistance of Imam Khamenei" in the field of military, economic, political, and cultural deterrent power of the Islamic Republic of Iran, is very important and has a lot to think about. Also, in the post-Corona context, increasing the power of countries such as China and Russia by creating cooperative bipolarities can affect international interactions and upset old equations. These conditions can move the world order from a unimultipolar to a multipolar and be a source of hope for governments that emerge as emerging powers in their regions.

In this article, we will try to use the "Theory of Resistance of the Supreme Leader" to examine the opportunities and challenges facing "Iranian-Islamic Civilization" as an "Emerging Power" in the "Emerging Global Multipolar Order" and the perspective of international interactions in the post-corona multipolar world.

\section{THEORETICAL FRAMEWORK}

Prior to the COVID-19 crisis, horizontal processes in the international system were expanding due to the ubiquity of governments, international civil society organizations, international NGOs, multinational corporations, and the international media. Multiplication (local, national, and trans boundary) and multidimensionality (political, economic, social, cultural, environmental, and military) of national sovereignty due to interdependence, increasing trade, the emergence and expansion of cyberspace, the compaction of time and space in geographical space, and the supremacy of international norms and regimes over international equations, led to the erosion of local sovereignty and the diminishing role of nation-states in enacting world laws and regulating international politics and economics in the post-Apostolic era ${ }^{3}$.

The impact of civil wars and crises on regional and international developments has increased due to the growth of violence and terrorism, as well as increased ethnic, religious, and racial conflicts, especially in deprived

\footnotetext{
${ }^{3}$ Saskia Sassen, Deciphering the Global: Its Scales, Spaces and Subjects, (London and New York, Routledge, 2007) \& Mohammad Reza Dehshiri, (2014). "Globalization and the International System", Quarterly Journal of Strategic Studies in Public Policy, Volume 5, Number 14, Spring 2014, 7-44
} 
countries, failed states, and semi-sovereignties. It happened due to the instability of semi-nationalist authoritarian or semi-authoritarian regimes, transnational and religious ethnic separatism, cross-border wars, as well as invisible wars such as poverty, unemployment, homelessness, hunger, malnutrition, infectious diseases, poor health conditions, repression and exploitation, racial discrimination, physical assassinations, inequality, and racial inequality. Violations of civil rights, degradation of the environment and human ecosystem, the activities of terrorist groups, especially postmodern terrorists who use bioterrorism and cyber-terrorism (using cyberspace and computer technology to attack targets), also affect regional and international order and stability, and the challenges become more complex and chronic in the age of globalisation 4 .

But the conditions of the COVID-19 pandemic crisis upset the status quo. Even in these circumstances, the most fundamental issue in international relations is still the issue of "change" in the international order, which is of great importance. There are different ways to express the concept of change in international relations. Explaining the transfer of power is one way to study and analyse change in international relations. Each established order represents a particular order of power in the international system, which has a definite period of rise and fall. As a result, the analysis and identification of the power pyramid and the factors influencing its stability and crisis have become the focus of understanding change in the international system. Hence, in some cases, the transfer of power has led to the disappearance of the existing order and the birth of a new order.

Historically, the primary critical factors in the system have been the decline of hegemonic power or the rise of a challenging actor's power. Accuracy in the history of this field is a good indication of the transformation of order during the rise and fall of the great powers, so now, with the decline of American power and the rise of China and other regional powers, the focus of analysis of international relations is shifting. Conditions that can promise a multidimensional order change the world towards a new geometry, in such

\footnotetext{
${ }^{4}$ T. Szentes, World Economics, 1-Comparative Theories and Methods of International and Development Economics, (Akademiai Kiado, Budapest, 2002) \& T. Szentes, World Economics, 2- The Political Economy of Development, Globalization and System Transformation, (Akademiai Kiado, Budapest, 2003)
} 
a way that the gradual transfer of power can be the basis for a transition to a just and humane order.

In this regard, the leader of the Islamic Republic of Iran, by proposing the "Theory of Resistance", sought to create conditions for being in the new world order. The "Theory of Resistance", which was put forward in Ayatollah Khamenei's statements on November 4, 2018, showed his belief in the essence and nature of civilizations. Perhaps it can be said that the main idea of the Islamic Revolution and the general direction of religious civilization is the Islamic resistance. Resistance is the opposite of passivity. Resistance is even more than mere defense. Resistance is at the heart of aggression and action and increases social and historical opportunities. Resistance is not only for its own survival, but in addition to its own preservation, it seeks to be effective.

The idea of resistance goes beyond nationalities, ethnicities, and religious affiliations and can bring all freedom-loving people with it. Resistance is a new idea that was born from the history of the struggle of Shiite scholars, reached maturity in the Islamic Revolution, and has spread today in the region and the Islamic world. Hence, in the slogans of the Islamic Revolution, the struggle of the barefoot and the oppressed against the arrogant and oppressors was raised. Of course, the idea of resistance is always associated with certain conditions because, on the one hand, it pursues lofty ideals and, on the other hand, it sees many dangers and obstacles ahead. The idea of resistance, while idealistic, is realistic and tries to humbly look at the scene of objectivity and reality in accordance with its historical conditions and possibilities ${ }^{5}$. Therefore, in this article, using the idea of resistance, we will examine international interactions in a multipolar world.

\section{"THEORY OF RESISTANCE"}

The reasons for the theory of resistance and why and how to explain it can be seen in the table below.

\footnotetext{
${ }^{5}$ Mohammad Hossein Motevalli Emami, "Capturing the pattern of the original confrontation of the Islamic Republic of Iran with Western civilization", Journal of Islam and Social Studies; Spring 2019, Vol. 24, pp. 57-78.
} 
Table 1: By Author

\begin{tabular}{|c|c|c|c|}
\hline $\begin{array}{l}\text { The Experience of } \\
\text { American Retreat } \\
\text { Against Resistance }\end{array}$ & $\begin{array}{l}\text { Low Cost of } \\
\text { Resistance }\end{array}$ & $\begin{array}{l}\text { The Futility of the } \\
\text { Compromise and } \\
\text { Surrender Strategy }\end{array}$ & $\begin{array}{l}\text { Successful } \\
\text { Experience of } \\
\text { Resistance } \\
\text { Thinking }\end{array}$ \\
\hline $\begin{array}{l}\text { Another reason for } \\
\text { expressing the theory } \\
\text { of resistance is the } \\
\text { need to recall the } \\
\text { political behaviour of } \\
\text { the United States and } \\
\text { Western hegemons } \\
\text { against the resistance } \\
\text { of nations. The } \\
\text { history of the foreign } \\
\text { policies of great } \\
\text { countries, especially } \\
\text { the United States, } \\
\text { shows that wherever } \\
\text { a nation or } \\
\text { government or even } \\
\text { a group has stood } \\
\text { against these } \\
\text { countries, they have } \\
\text { retreated. But in the } \\
\text { face of } \\
\text { backwardness, } \\
\text { countries have not } \\
\text { only failed to do what } \\
\text { they wanted, they } \\
\text { have gone a step } \\
\text { further. }\end{array}$ & $\begin{array}{l}\text { Another reason } \\
\text { for the } \\
\text { Enlightenment } \\
\text { about } \\
\text { resistance is } \\
\text { that among the } \\
\text { solutions to } \\
\text { confront the } \\
\text { system of } \\
\text { domination, } \\
\text { including one- } \\
\text { way interaction, } \\
\text { compromise } \\
\text { and } \\
\text { commitment, } \\
\text { retreat and } \\
\text { surrender, } \\
\text { passivity and } \\
\text { indifference, } \\
\text { etc., } \\
\text { "resistance" is } \\
\text { one of the least } \\
\text { expensive } \\
\text { solutions, but it } \\
\text { will also be } \\
\text { useful. }\end{array}$ & $\begin{array}{l}\text { The strategy of } \\
\text { compromise and } \\
\text { surrender to the } \\
\text { domination system } \\
\text { has shown its } \\
\text { ineffectiveness in } \\
\text { the occupied } \\
\text { territories and has } \\
\text { resulted in nothing } \\
\text { but backwardness } \\
\text { and identity crisis. } \\
\text { The situation in } \\
\text { Saudi Arabia and } \\
\text { the repeated } \\
\text { pressures from the } \\
\text { US government } \\
\text { are a good } \\
\text { example of the } \\
\text { situation of } \\
\text { surrendering to } \\
\text { the demands of } \\
\text { the oppressors of } \\
\text { the domination } \\
\text { system. }\end{array}$ & $\begin{array}{l}\text { A look at the } \\
\text { situation in the } \\
\text { Middle East shows } \\
\text { that the nations } \\
\text { that have taken } \\
\text { the path of } \\
\text { resistance have } \\
\text { not only regained } \\
\text { their dignity and } \\
\text { been freed from } \\
\text { the humiliation of } \\
\text { submission and } \\
\text { decision-making } \\
\text { by foreigners, but } \\
\text { they have paved } \\
\text { the way for their } \\
\text { progress. For } \\
\text { example, the path } \\
\text { that led to the } \\
\text { victory of the } \\
\text { Resistance Front in } \\
\text { Syria. }\end{array}$ \\
\hline
\end{tabular}


Strategies for the Practical Promotion of "Resistance" include:

Fig 1: By Author

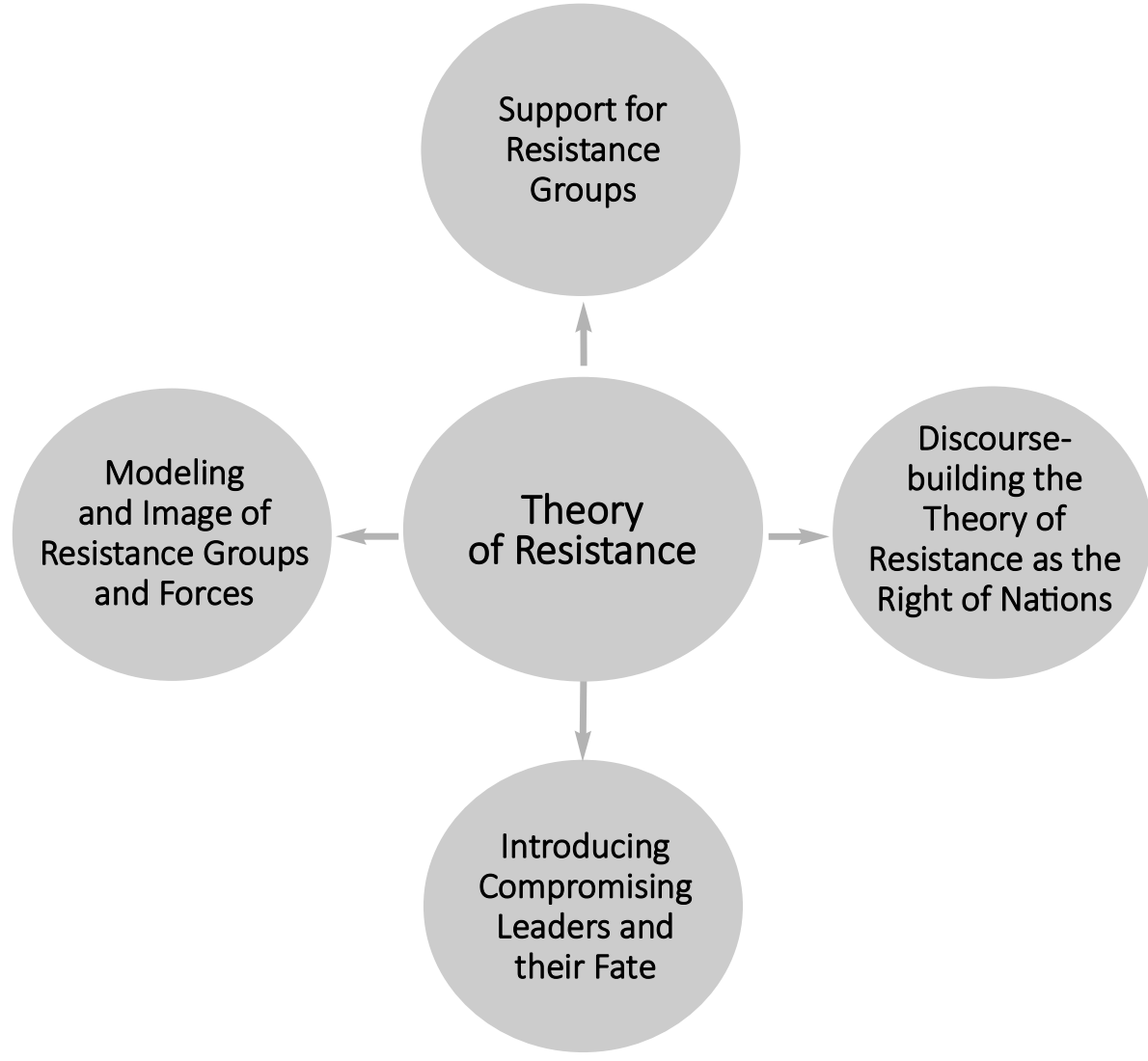

THE HISTORY OF THE NEW WORLD ORDER

After the collapse of the Soviet Union and the end of the Cold War, the United States, seeking world leadership, seized the opportunity and, following Iraq's invasion of Kuwait, introduced a new policy under which the international community would be transformed into a new order. Since then, the "Theory of the New World Order" has been proposed and welcomed by some leaders, especially in Western countries. Of course, the United States 
had long sought to impose its leadership on the world before the Persian Gulf crisis and the end of the Cold War.

Based on the theory of neoliberal institutionalism, with the end of World War II, the sovereignty of states was reduced and regional and international organisations gained more sovereignty in international relations. This trend first led to the discussion of globalisation in the field of economics and then was extended to other areas. With the outbreak of 9/11, doubts arose about the realisation of a new world order, and the existence of such an order was obscured.

Some authors have described this new world order as desirable: "If the new order is based on justice, peace, democracy, the development of human rights and international law and strives between the legal order, the political and economic order, and the morality of the world to create a lasting balance, one can hope for its prospects." Any alternative system in the future must create a moral order in which the needs of all human beings are met and encourage a kind of interdependence and solidarity between different races and nations.

It is natural that such a desirable order should establish positive international relations based on genuine and sincere partnerships between all countries, strong and weak, north and south, rich and poor. The UN Charter can be used as a framework for the new world order, but its shortcomings and gaps in many cases, such as the environment, poverty, terrorism, and nuclear threats, need to be addressed. "In such a system, peace and security are a necessity through the development and cohesion of the collective security system guaranteed by the United Nations. ${ }^{6 \prime}$

However, some of these ideals were voiced by George W. Bush after the repression of Iraq: "We have an opportunity to create a new world order for ourselves and future generations. A world in which the rule of law, not the law of the jungle, governs the conduct of nations." Referring to the future role of the United Nations, he stressed that this new world order is one in which a credible United Nations can use its role to safeguard peace to fulfil the Charter and the aspirations of its founders. ${ }^{7}$ But in practice, we witnessed actions completely contrary to these slogans.

Of course, Noam Chomsky described the nature of the new world order led by the United States as full of racism and hypocrisy, saying that Saddam's

${ }^{6}$ Ali AsgharKazemi, The End of Politics and the Last Myth, (Tehran, Qomes Publishing, 2002)

${ }^{7}$ Ali Asghar Kazemi, International Relations in Theory and Practice, (Tehran, Qomes Publishing, 1993) 
attack on the Kurds was widely reported, prompting a public outcry that forced Washington to take reluctant steps to protect victims of Aryan descent. But Saddam's more devastating attacks on Shi' ite Arabs in the south did not receive widespread news coverage or cause much concern, while Turkey's atrocities against the Kurds were largely ignored by the US media. "It continues today"8.

In this regard, the division of the world between the great powers was another feature of the new world order. Almost all Western analysts believed that Western Europe would be one pole, and the United States another. Accordingly, the United States will have to relinquish power in the new order, and economic giants such as Japan, Germany, China, and military countries such as Russia will not remain silent in the face of the United States. Of course, under these circumstances, the world situation changed somewhat, and in the new structure, in which economic considerations were more important, he introduced Japan and Germany as two serious rivals for the United States. "America's internal problems and the creation of new poles around the world by China and Islamic countries have strengthened this analysis and change in the world order."

After the collapse of the Soviet Union, the United States, as a superpower, sought to maintain its hegemony in the world through peace negotiations, disarmament, and human rights issues, which lasted for nearly two decades. But because of other economies and other discourses, it could not continue.

So the United States used another method, and that was to present a hypothetical enemy. "Creating a hypothetical enemy as an international threat is a traditional way of trying to implement new geopolitical plans on a global scale and allocating human resources to it." With the collapse of the Soviet Union and the elimination of that international threat, the United States sought to portray the resurgence of Islam in Iran and other Islamic countries as a "fundamentalist" threat. "For this reason, Islamic and revolutionary movements have been wrongly identified by potential political and media circles in the West as potential threats to international security." ${ }^{10}$

\footnotetext{
${ }^{8}$ Noam Chomsky, Old and New World Orders, translated by Mahbod Iranitalab, (Tehran, Etelaát Publications, 1996)

9 Afzali, Rasoul, "The Third World in the New World Order", Neshat Newspaper, June 1999, Vol. 24, 27/4/78

${ }^{10}$ Roozitalab, Zahra and Pirooz Mojtahedzadeh, "The weak foundations of the theory of the new world order", Abrar Newspaper, Feb 1997, 12/23/76
} 
Of course, after the COVID-19 crisis and the emergence of China's special economic position as an unrivalled economic power, the situation was different. However, it seems that the United States has no more purpose than to design a new world order, and that is to maintain its hegemony and dominance over the world based on its short-term and long-term interests, and the world order is in fact an excuse to maintain and perpetuate this domination at the international level.

International relations theorists have offered different analyses of the situation in the early 21st century, naming these years under different headings. Farid Zakaria, a contemporary thinker in international relations, has described this process as "the emergence of others." Kishour Mahbubani emphasises the fact that the rise of Japan, China, India, South Korea, and other Asian countries has created new centres of world power in Asia in terms of demographics, economy, trade, technology, etc. Therefore, an appropriate description of the "emerging international structure" has been made ${ }^{11}$.

Also, many terms have been used in the last two decades to describe the distribution of global power among the units of the international system. Many writers have suggested that we are witnessing the expansion of a "polar world". The basic examples of this approach are Nile Ferguson's concept of "unipolarity", Simon Sarfati's concept of "polarity", the concept of "G-zero" by lan Bremer and Norril Rubini, or the "absence of polarity" proposed by Richard Haas. These implications suggest that the end of the "unipolar moment" did not lead to a multipolar structure but to a power vacuum because no unit is willing or able to lead. According to some writers, the lack of overpowering power in the international system has led to the emergence of "no one world" or "anarchy" in the international system. In a world of "zero sum", no power can dominate the system. In this world, foreign powers such as China, the United States, Europe, and Russia compete for influence in different regions. However, it is not possible to fully shape its political, social, and economic realities. ${ }^{12}$

Other researchers point out that the structure of the system is moving toward a multipolar one, but in a different form than in the past. The concept

${ }^{11}$ Fereshteh Mir Hosseini \& Mohammad Rahim Eivazi, "Future scenarios of the geopolitical position of the Islamic Republic of Iran in the West Asian regional power system on the horizon of 2031", Journal of Basij Strategic Studies, Volume 22, Number 83 / Summer 2019, pp. 143-169, 152

${ }^{12}$ E. S. I Lecha, \& et al. "Re-conceptualizing orders in the Mena Region, the Analytical Framework of the Menara Project", Methodology and Concept papers, $(2016,70-71)$ 
of asymmetric multipolarity was introduced by Thomas Reynard. Huntington commented in the article that "America is the only superpower." He believes that global politics has moved beyond the Cold War bipolar system and the post-Cold War unipolar phase, culminating in the Persian Gulf War, and now before entering the 21st century multipolar era. It is the transition from one or two decades of the mono-polar era. ${ }^{13}$

According to various research reports conducted by various international organizations, the United States is no longer just a superpower, but also a number of other great powers with whom the United States is forced to cooperate and participate in resolving global issues. The 2018 Strategic Trends report notes that while the United States will be a major player in global affairs, the long-term role of the United States' international leadership is under threat. This is partly due to structural changes in the international system. As the challenges of future scenarios increase, the geopolitical position of the Islamic Republic of Iran in the power system of the West Asian regions on the horizon of 2031 is also strengthening. ${ }^{14}$

The report, "Strategic Future Trends Started Today," notes that over the next thirty years, a multipolar world will develop in which the current liberal international order and its institutions will be under greater pressure. It is also claimed that by 2025, economic power will shift from the Atlantic to the Pacific, and by 2050, the Chinese and Indian economies are likely to overtake the United States. Furthermore, if current trends continue, China will be the world's largest economy, a major military power, and the largest importer of natural resources by 2025. India is also likely to continue its rapid growth and continue to strive for a multipolar world as an economic power. Russia also has the potential to become richer, more powerful, and more self-sufficient by $2025^{15}$. The political and economic power of other countries, such as

\footnotetext{
${ }^{13}$ According to: Mohammad Reza Dehshiri, \& Muslim Golestan, "Behavioral Model of Major Powers in Managing International Crises in a Unipolar System", Quarterly Journal of Political Science, 2016, Volume 11 (3,) pp. 79-124, 84

${ }^{14}$ Mohammad Rahim Eivazi, and Mahsa Fallah Hosseini, "Islamophobia and the scenarios before it", Journal of Political Studies of the Islamic World, 2020, Volume 6 (3,) pp. 75-92.

${ }^{15}$ Global Strategic Trend the Futures Starts Today, Ministry of Defense, Strategic Trends, Key Developments in Global Affairs, Center for Security Studies, 2018, ETH Zurich, available at: www.css.ethz.ch/publications/strategic-trends
} 
Indonesia, Iran, and Turkey, is also expected to increase. Thus, the theory of a multipolar system seems to be more appropriate for describing the longterm future of the structure of the international power system.

\section{THE MODEL OF IRANIAN ISLAMIC CIVILIZATION}

In line with the new world order and emphasising the Theory of Resistance proposed by the Leader of the Islamic Republic of Iran, the model of Iranian Islamic civilization, with emphasis on religion and Godcenteredness, the centrality of divine laws and the Qur'an, effort and struggle, science and knowledge, rationality, justice-oriented and orbital ethics, is trying to gain a place first in the region of West Asia and then in the new world order.

Fig 2: By Author

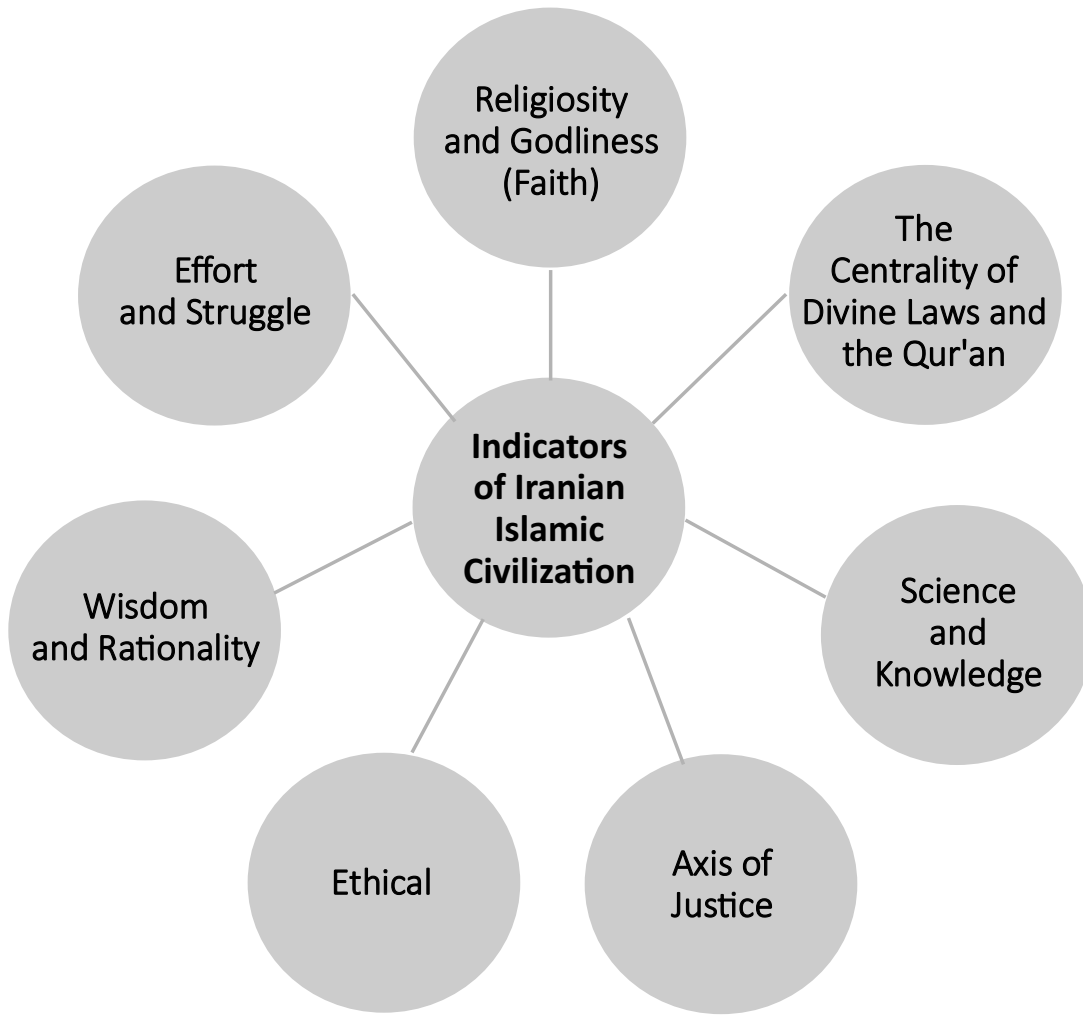


The pattern of this civilization can be plotted in the chart below, and, of course, there are opportunities and challenges in this discourse that we will address in order to achieve global status.

\section{THE OPPORTUNITIES AND CHALLENGES OF IRANIAN ISLAMIC CIVILIZATION}

Geographically and territorially, Islamic civilization began to grow in a region of the world that the Holy Qur'an describes as ignorance. Therefore, it can be argued that in terms of social and geographical talent, the land of Hejaz lacked significant features for the formation of a great world civilization. But history shows that the Prophet (PBUH), by using small capacities and careful planning to build a great civilization, first made all the inhabitants of the Arabian Peninsula aware of a divine and humanizing message, and then, with planned efforts and the spread of revelatory ideas, laid the core of the great Islamic civilization.

In this regard, the Leader of the Islamic Republic of Iran, relying on the method of the Holy Prophet (PBUH) as a good model of the Islamic Ummah, introduces the new Islamic civilization as a superior idea and plan that has the ability to attract Muslim nations to itself. Finally, it has a soft effect on uniting and moving Islamic societies to build a great world power. The creation of a new Islamic civilization is an intellectual movement and thought that will pave the way for the construction of a new Islamic civilization by influencing the Islamic Ummah. This original civilization and this emerging power could have something to say in the present age and are places to pay attention to. By relying on attributes such as religion-oriented, implementing divine laws, rationalism, avoiding extremism, social justice, and economic prosperity, as well as emphasising basic knowledge and science-based civilization, the original Islamic civilization can have many opportunities in the world and have a high position among emerging disciplines. ${ }^{16}$

It is clear that the new Islamic civilization is based on a deep knowledge and correct implementation of the teachings of Islam, because in principle,

\footnotetext{
${ }^{16}$ Majid Khari Arani \& Zahra Ali Akbarzadeh Arani, "Principles and Components of Modern Islamic Civilization with Emphasis on the Thoughts of the Supreme Leader", National Conference on Modern Islamic Civilization, (Tehran, Shahed University, 2015).
} 
this civilization will base its growth on the axis of religion. Naturally, in order for the new Islamic civilization to be able to have its material and spiritual power together, it must have a comprehensive and, of course, refined view of religion free from lethargic deviations. This civilization is based on pure Islam and is far from destructive superstitious readings. Such a conception of religion, as in the early days of Islam, was able to lead an ignorant society towards the creation of a great world civilization. It will undoubtedly be effective in the age of human progress and could be like an emerging power in the age of order. The new ones have a place to show off their power. What is certain is that, as the title of the new Islamic civilization suggests, the most important and main indicators of the new Islamic civilization are showing the face of religion in the course of social life.

The signs of religion in a society and civilization are focused on its laws. Until the divine laws are implemented in society, it cannot really be called a pivotal word. So, without the application of divine laws in individual and social life, not only will this vital thing not happen, but it will also be impossible to call it Islamic civilization in principle. Therefore, one of the main ways to create a new Islamic civilization is to try to implement divine laws in Islamic society. This process increases the power of the spiritual and soft influence of the new Islamic civilization among the nations and prepares the Islamic world to become a power in line with the interests of the Islamic Ummah. ${ }^{17}$

It is also important to note that nations have never crossed the path of extremism in order to progress and excel, but it must be said that the main requirements for the development of a civilization and the modernization of its structure in accordance with the needs of the new time and place are rationalism and legal mechanisms. The root of division among the Islamic Ummah is the failure to stay away from rational methods and to fall into the trap of extremism and heresy. The enemies of the Islamic world are trying to lead the Islamic Ummah towards extremism in various ways. Rationalism and the avoidance of extremism cause the Islamic Ummah to recognise its true interests quickly and accurately in the first place, and by maintaining moderation and rationality, to provide the means of unity and lay the foundations for the movement of the new Islamic civilization. ${ }^{17}$ Hamid Zamani Mahjoob, "Components and Indicators of Islamic Civilization", Conference
of the Research Institute of Islamic Sciences, (Imam Sadegh (AS) University, 2017). 
The Islamic world in general and Iran in particular, due to the rich underground resources, especially energy, and the motivated manpower, have very strong economic support. The reasons why the huge capital of Islamic lands has not been able to give a successful economic face to the whole Muslim community are mismanagement and a lack of regulation of co-operative economic relations among Muslim countries. The formation of a new Islamic civilization as a planning and guiding power can play a very effective role in the production of productive and endogenous employment in the Islamic world and lead them to their true economic position and the balance of raw sales and dependence. This has the potential to transform the economy outside of the Islamic world into an equal and capitalizable economic interaction.

In the face of these opportunities, the Islamic world also faces challenges. One of the major problems for Muslims today is their economic weakness, or the waste of their capital and consumerist culture, given that they have the underlying power for an economic leap. Therefore, it should be emphasised as an attractive axis among the Muslim community that the new Islamic civilization will provide a better future for the children of the Islamic world, although the enemies of Islamic Iran may try to come up with this idea through misinterpretations and self-made interpretations. The revival of Islamic civilization is tantamount to trying to establish hegemony and leadership in the Islamic world and creating divisions within and outside Islamic states, but the reality is that the new Islamic civilization is based on justice and efforts to preserve material and spiritual capital. It is possible for Islamic countries to be established for the Islamic Ummah, especially Muslim nations.

The gap between developed and underdeveloped countries can be boldly explored in their approach to science and technology. The migration of knowledge from the Islamic civilization to the West in the third and fourth centuries of Islam caused the Western world to move towards progress in the fields of economy, military, etc., in contrast to the Islamic world in a period of little attention and no connection between the public body. Society and scientific centres have lost the path of growth and development and finally look for ways to progress by looking at the West and imperfectly imitating them.

Today, one of the main ways to revive the new Islamic civilization is to rely on the knowledge of the scientists of the Islamic world and move towards discovering shortcuts to promote science within Islamic societies. Thus, civilised Islamic society must inevitably pave the way for the advancement of 
its goals through the path of indigenous knowledge and transform its face with endogenous knowledge, which can be both an opportunity and a challenge. Undoubtedly, the revival of the new Islamic civilization depends on the scientific efforts of the Muslim elite, and this is the path that Muslims have taken before, inspired by Islamic teachings, and in recent years, with the emphasis of the leadership of the Islamic Republic of Iran on intelligent and educated Iranian-Islamic youth. With full confidence and in light of the support of the Islamic system, they have taken steps towards the development of knowledge and amazing scientific advances, and this promises the formation and strength of a new Islamic civilization in the very near future.

\section{CONCLUSION}

As mentioned, emerging orders are taking shape and global geometry is changing. This refers to those who did not succumb to US hegemony and the unipolar order. New orders create novel situations and a variety of opportunities and challenges. In this regard, the Supreme Leader of Iran believes that the current situation can bring opportunities for Iranian Islamic civilization. One of the key concepts proposed by him, which is derived from the main discourse of the Islamic Revolution, is the keyword "Theory of Resistance", which finds meaning in the face of domination, compromise, and submission.

His strategic advice is to promote this theory both theoretically and practically, so that it can be used as a framework for "discourse-building, networking, and stream-making" resistance to the system of domination not only in the geography of Islamic Iran, but in the realm of all nations in a free world. The "Theory of Resistance" is a framework for thinking, planning, and finding solutions for the progress of Islamic Iran.

According to him, today it is necessary to define resistance both in the field of foreign policy and foreign interactions and in the domestic dimension, and according to this macro theory, the strategy of "deepening and internalizing resistance" should be put on the agenda and redefined and explained based on it. "Political resistance", "socio-cultural resistance" and "economic resistance" to further deepen the components of the soft power of the Islamic Revolution in the country and beyond its borders, and from that path of progress and resistance against the all-out combined war of the enemy. 
By emphasising the theory of resistance and establishing the deterrent aspect of this theory in all political, economic, military, social, and cultural fields, Iran can achieve self-sufficiency in all areas and therefore will not need foreigners to solve internal problems. Also, according to this, the Iranian-Islamic model of progress can be a way forward and the Iranian-Islamic civilization in the new world order can have a place for emergence and expression.

\section{BIBLIOGRAPHY}

Afzali, Rasoul, (1999). "The Third World in the New World Order", Neshat Newspaper, Vol. 24, 27/4/78

Burton, John W., (1972). World Society, Cambridge University Press

Chomsky, Noam, (1996). Old and New World Orders, translated by Mahbod Iranitalab, Tehran, Etelaát Publications

Dehshiri, Mohammad Reza \& Golestan, Muslim, (2016). "Behavioral model of major powers in managing international crises in a unipolar system", Quarterly Journal of Political Science, Volume $11(3$,$) pp. 79-124$

Dehshiri, Mohammad Reza, (2014). "Globalization and the International System", Quarterly Journal of Strategic Studies in Public Policy, Volume 5, Number 14, Spring 2014, pp. 44-7

Eivazi, Mohammad Rahim and Fallah Hosseini, Mahsa, (2020). "Islamophobia and the scenarios before it", Journal of Political Studies of the Islamic World, Volume $6(3$,$) pp. 75-92$

Global Strategic Trend the Futures Starts Today, (2018). Ministry of Defense

I Lecha, E. S. \& et al. (2016). "Re-conceptualizing orders in the Mena Region, the Analytical Framework of the Menara Project", Methodology and Concept papers

Kazemi, Ali Asghar, (1993). International Relations in Theory and Practice, Tehran, Qomes Publishing

Kazemi, Ali Asghar, (2002). The End of Politics and the Last Myth, Tehran, Qomes Publishing

Khari Arani, Majid and Zahra Ali Akbarzadeh Arani, (2015). "Principles and Components of Modern Islamic Civilization with Emphasis on the Thoughts of the Supreme Leader", Tehran, National Conference on Modern Islamic Civilization, Shahed University 
Mir Hosseini Fereshteh \& Mohammad Rahim Eivazi, (2019). "Future scenarios of the geopolitical position of the Islamic Republic of Iran in the West Asian regional power system on the horizon of 2031", Journal of Basij Strategic Studies, Volume 22, Number 83 / Summer 2019, pp. 143-169

Motevalli Emami, Mohammad Hossein, (2019). "Capturing the pattern of the original confrontation of the Islamic Republic of Iran with Western civilization", Journal of Islam and Social Studies; Spring 2019, Vol. 24, pp. 57-78

Roozitalab, Zahra and Pirooz Mojtahedzadeh, (1997). "The weak foundations of the theory of the new world order", Abrar, 12/23/76

Sassen, Saskia, (2007). Deciphering the Global: Its Scales, Spaces and Subjects, London and New York, Routledge

Szentes, T., (2002). World Economics, 1- Comparative Theories and Methods of International and Development Economics, Akademiai Kiado Budapest

Szentes, T., (2003). World Economics, 2- The Political Economy of Development, Globalization and System Transformation, Akademiai Kiado Budapest

Zamani Mahjoob, Hamid, (2017). "Components and Indicators of Islamic Civilization", Conference of the Research Institute of Islamic Sciences, Imam Sadegh (AS) University

Websites:

Strategic Trends 2018, Key Developments in Global Affairs, (2018). Center for Security Studies, ETH Zurich, available at: www.css.ethz.ch/publications/ strategic-trends 